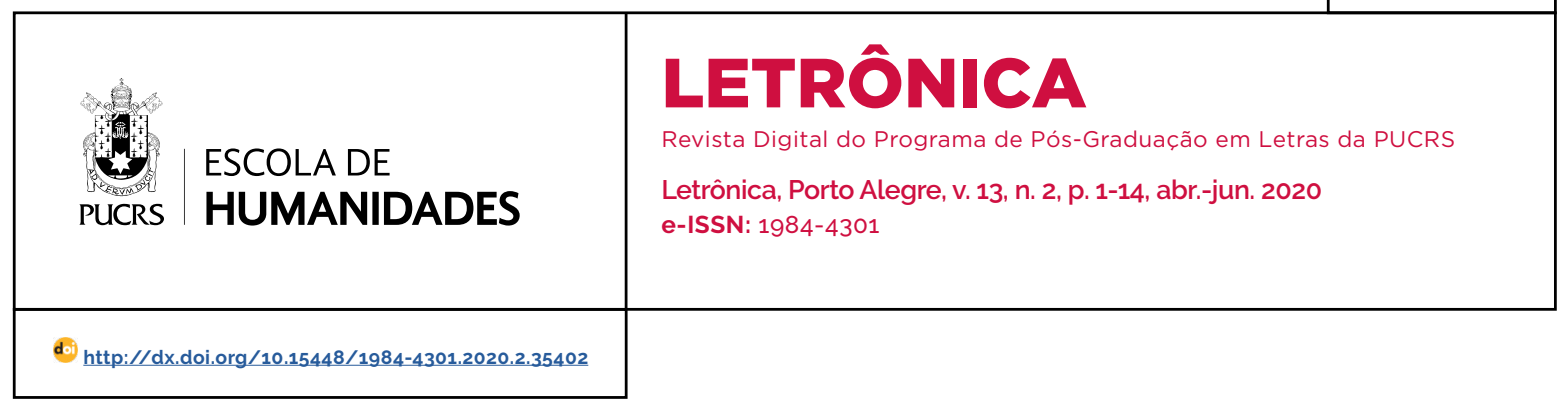

\title{
Temperança de Tonus: agora vai ser assim contra a intolerância
}

Tonus Temperance: now it will be so against intolerance

\section{Daniel de Oliveira \\ Gomes $^{1}$}

orcid.org/0000-0003-0325-9846 setepratas@hotmail.com

Recebido em: 26 ago. 2019. Aprovado em: 15 dez. 2019. Publicado em: 13 ago. 2020.

\section{(c) (i)}

Artigo está licenciado sob forma de uma licença Creative Commons Atribuição 4.0 Internacional.
Resumo: O presente artigo estuda a poesia de Leonardo Tonus. Este autor publicou recentemente seu livro "Agora vai ser assim" pela editora Nos (2018). Investigamos uma poesia que acusa a intolerância do presente a partir de um estilo bem mesclado e complexo. Procuramos uma relação com a figura da Temperança, do Tarot. Analisamos sua biografia, enquanto desterritorializado e, também, vários de seus versos. Recorremos, teoricamente, à geografia humana de Milton Santos; à sociologia da modernidade liquida de Zigmunt Bauman. Uma poesia altamente critica que questiona a intolerância, o preconceito e a xenofobia dos tempos atuais.

Palavras-chave: Temperança. Intolerância. Poesia. Xenofobia.

Abstract: This article explores the poetry of Leonardo Tonus. This author recently published his book "Agora vai ser assim" by Editora Nos (2018). We have investigated a poetry that accuses the intolerance of the present from a well-blended and complex style. We hake looked to find a relation between the figure of temperance, of the Tarot. We have analyzed his biography, as deterritorialized and also several of his verses. We have, theoretically, resored to the human geography of Milton Santos; to the sociology of the liquid modernity of Zigmunt Bauman. A highly critical poetry that questions the intolerance, prejudice and xenophobia of current times.

Keywords: Temperance. Intolerance. Poetry. Xenofhobia.

"Vaga-lumes de uma história/ que gagueja/sonhávamos comunidades/de desejo./ sonhávamos desejos."

(TONUS, Leonardo, 2018, p. 76).

\section{Introdução}

Uma poesia fluida sobre o presente, a modernidade líquida, preconceitos sólidos. A água não pode jamais estar parada. Elemento circulante e vital. Tonus não é tão simplesmente um poeta da nova geração, mas sim um poeta da nova "regeneração". Com isso, digo que Tonus é o poeta da regeneração do presente. Milton Santos postulou que: "hoje, a mobilidade se torna uma regra. O movimento se sobrepõe ao repouso [...]" (SANTOS, 1996, p. 222). Neste presente da extrema mobilidade, da deslocalização, busco a figura da regeneração.

Ponderemos uma mística divinatória e sempre imprevisivel, a regeneração vem a ser "La Tempérance" do Tarot de Marseille. Do 
latim, "temperare", como explicaria o livro do astrólogo Didier Colin: "Tempérance et tempérer viennent du latin temperare, qui signifie disposer harmonieusement et à leur place tous les éléments qui forment un tout, ou combiner, mélanger, doser dans de justes proportions. Mais temperare est issu lui-même de tempus, temps" (COLIN, 1999. p. 79). Temperar é também a ciência de dosar, mesclar, misturar. Um poeta da temperança é um autor preocupado com as deslocalizações do contemporâneo; um poeta cheio de temperos, ele sabe temperar, eminente batalhador nos presenteia poemas com equilibrio e dissonância ao mesmo tempo, pois deve ser um poeta das mesclas, da mestiçagem, da fluidez dos peregrinos, da complexidade do social e da música: "[...] en musique, il existe un système tempéré qui désigne une gamme dans laquelle un bémol et un dièse qui suivent sont remplacés par un ton intermédiaire que l'on nomme 'tempérament.' C'est selon cette règle musicale que Jean-Sébastien Bach a composé son fameux Clavecin bien tempéré. (COLIN, 1999, p. 80). Seria possivel qualificar a poesia de Tonus como a de um poeta temperamental? Um poeta social? No breve ensaio "Leonardo Tonus, poesia social", o crítico literário Flavio Viegas Amoreira qualifica do seguinte modo:

Tonus é um militante visceral das letras, grande voz a levar a literatura brasileira em França e embaixador do melhor que se faz nas escrituras lusoparlantes no Velho Continente. Formalissima apresentação para quem fala e faz literaturas de vanguarda, - sim no plural da caleidoscópica produção brasileira em poesia, prosa e "proesia", a nova concepção de gêneros indeterminados 'deleuzianamente' amalgamados. Denunciar sem cair no panfletário, expor sem didatismo, amplificar o sentido de ágora cosmopolita nunca em detrimento da poeticidade. Leonardo trafega célere e sereno entre experimentação e a referida denúncia social: não o 'vanguardoso' experimentalismo, a experimentação calculada com literalidade sem peias, um verso audaz, escorreito e não menos densamente comunicacional. Em meu oficio gozozo de rastreamento do que surge em poesia brasileira me deparo com mais esse esforço de inventividade pelo conteúdo sem descuido da mesma criação sutilmente torneada na forma. Quem diria na alvorada dum século high-tech fosse necessário a ingente luta contra novos fascismos?! Quem poderia supor a desigualdade social se agudizasse planetariamente? Na nobre esteira de Romain Rolland e Éluard nosso autor expõem o câncer da indiferença feito anátema pós-moderno. Tonus evocatório na medida certa do intertextual cita no contexto de sua amplitude Clarice Lispector, Samuel Rawet de quem é especialista e a quem o Brasil deve um resgate, Saint-John Perse que ecoa poeta atlântico que também é e sem nomear percebo forte influência enriquecedora dos russos lessênin, Maiakovski e Anna Akhmátova (AMOREIRA, [2018], p. 1).

Tonus nos apresenta uma poesia bem mesclada no estilo, em pitadas barrocas, como temperos de Bach. Vislumbro as pistas, em "Agora vai ser assim", de seu autor como sendo "l'ange de la communication" da poesia do presente, da poesia social do presente. Aqui, também tentarei trabalhar os paradoxos de sua poesia, de quem ocupa a postura de poeta social não vanguardoso, olhando sublimemente este novo social, em um mundo onde, como diria Milton Santos, "[...] os homens vivem cada vez mais amontoados lado a lado em aglomerações monstruosas, mas estão isolados uns dos outros" (SANTOS, 1994, p. 40). Conforme diria o geógrafo socialista, "os progressos de nossa infeliz civilização" (SANTOS, 1994, p. 43) criariam mais desunião do que, realmente, união entre as pessoas. Para Santos, a união no espaço é virtualizada pela sensação da proximidade, quando, de fato, temos muito mais dados que proximidade real, em geral, uma dimensão de muitas informações circulando (acumulo de informações, de dados, de tecnologias, de exposição de sentidos etc.), muito mais esta do que uma dimensão de comunicação real (temperança, ligação orgânica, amorosa entre as pessoas).

Interessante ressaltar mesmo, para entender a poesia de Tonus, essa distinção entre as dimensões de "informação" e de "comunicação", percebendo-o como um poeta que labuta desde informações do presente (os terrores sociais do presente) para então reivindicar, poética e utopicamente, um mundo com mais comunicação real e tolerância com a diferença. Leonardo Tonus o faz desde uma condição privilegiada. Honrado e longe. Titulado 
"Chevalier", em duas ocasiões², pelos ministérios franceses, Leonardo Tonus é um poeta do nosso tempus. Propondo um olhar sublime, jamais desdenhoso, e simultaneamente, atravessador, fraterno, como mirada deste tempus e suas contradições mundiais no plano social e afetivo.

O arcano da Temperança (distinto daquele do Mago, que faz velhos truques de alquimias) é um arcano do extremo presente, da vitalidade, defensor da vida, da alegria, o de um mensageiro com grandes asas, no caso do poeta, um par de condecorações que por si o sustentam a "10.000 quilômetros de si mesmo", como diz um verso seu, lidando com as travessias, com as pontes, os oceanos cruzados, as angústias peregrinais, as passagens no mundo. Após muitas "desrotas", Tonus é, hoje, Mestre de Conferências junto à Sorbonne Nouvelle, e bem teria razões para ter perdido a modéstia, com os louros internacionais, atravessados os portais de Paris, contrabandeado à zona do sucesso acadêmico. Mas, ao contrário, parece que a nutriu, essa identidade humilde, com a hospitalidade do estar-em-comum (com os des-rotados), com as águas da temperança.

\section{1 Águas da Temperança}

Como mesmo dirá Cintia Moscovich, na orelha da obra: "[...] em todo volume existe um sentido sublime de humanidade sintonizado com valores transcendentes e inegáveis, identificado com os despossuidos de todo tipo em todo mundo, fato que estabelece com o leitor uma empatia profunda e imediata" (MOSCOVICH, 2018, p. 1). Seu diálogo é absolutamente aberto, mas não porta a característica do testemunho estático ante as intempéries, não é testemunho como sinônimo de acomodamento ou moderação em meras lágrimas distantes, justamente ao contrário, o que, em verdade quer, e seus versos de ouriço dizem bem: "Quero que minha voz migrante ecoe / na espera do lugar algum" (TONUS, 2018, p. 79). ${ }^{3}$ Falamos de uma poesia surpreendentemente portadora da temperança em sua mística cabalista/alquimista, como fluida, móvel, enérgica, trazendo-nos não apenas a denúncia do presente, dos males do presente, mas a sabedoria inata de que, com doçura poética, equilibrio e, claro, a moderação, se soubermos manter as energias poético-politicas em circulação, a esperança na dimensão da diferença continua. Uma poesia de luta, porque é indignada com, por exemplo, a questão dos refugiados. Alguns versos confessionais trazem, por vezes, uma estranha culpa (o eu-lírico põe-se como o próprio ser-humano), como quando diz, no poema Saúva, que desconhece os nomes dos mendigos de seu bairro, das mães de Dresden, Saravejo e Síria. "Eu não salvei a criança que se afogou no/ Mediterrâneo" (TONUS, 2018, p. 62). Remete, claro está, ao caso da criança síria falecida em 2012 por afogamento, junto com outros tantos sírios, no mar Mediterrâneo, na viagem entre Turquia e Grécia. Alyan Kurdi estava com 3 anos de idade e seu corpo com camisetinha vermelha foi resgatado em uma praia turca próxima a Bodrum. Em outro poema, "Conchas", Leonardo Tonus diz que, no fundo de sua cama, ouve as conchas do Mediterrâneo, gostaria de ser concha, de "[...] murmurar segredos/ às conchas do Mediterrâneo/ que sorriem / à chuva de homens" (TONUS, 2018, p. 17). As fotos do pequeno cadáver nas espumas do mar mediterrâneo com o semblante para a areia, com um paramilitar tranquilamente tomando

\footnotetext{
2 Não é preciso superdimensionar Leonardo Tonus, ele é mestre de Conferências da Sorbonne e condecorado como "Chevalier des Palmes académiques" e também "Chevalier des Arts et des Letres" pelos Ministérios franceses.

3 Leonardo Tonus imigrou por questões econômicas, nos anos 1980, para França. Na condição de migrante econômico, seguramente sofreu tendo sido alvo das suspeitas naturais desse processo, na França. Como diria Bauman: "Aonde quer que vão, os refugiados são indesejados, e não deixam dúvidas sobre isso. Os identificados como "migrantes econômicos" (ou seja, pessoas que seguem os preceitos da "escolha racional" e assim tentam encontrar formas de subsistência onde elas podem ser encontradas, em vez de ficarem onde elas não existem) são abertamente condenados pelos mesmos governos que fazem de tudo para que a "flexibilidade da força de trabalho" se transforme na principal virtude de seu eleitorado, e que exortam os desempregados de seus próprios países a "correrem atrás" dos compradores de mão-de-obra. Mas a suspeita de motivação econômica também respinga sobre aqueles recém-chegados que, não muito tempo atrás, eram vistos como pessoas no exercício de seus direitos humanos procurando abrigar-se da discriminação e da perseguição. Por associação repetida, a expressão "em busca de asilo" adquiriu um sabor pejorativo. Grande parte do tempo e da capacidade cerebral dos estadistas da "União Europeia" é empregada no planejamento de formas cada vez mais sofisticadas de fechar e fortificar fronteiras, bem como dos processos mais eficazes para se livrarem de pessoas em busca de pão e abrigo que, apesar de tudo, tenham conseguido cruzá-las. [...]" (BAUMAN, Zygmunt, Amor Liquido, p. 116).
} 
notas ao lado ou removendo-o, tornaram-se um dos simbolos virtuais do terror contemporâneo. E Tonus se pergunta: "Você já ouviu o silêncio das conchas do mediterrâneo?" (TONUS, 2018, p. 17). Tonus pergunta ao leitor se ele já ouviu "o sopro de uma bomba num mercado de Istambul?" (TONUS, 2018, p. 17).

É como se Tonus, suspenso e bem equilibrado por um par de asas azuis, segurando dois vasos entre as mãos, fizesse a revelação/afronta de uma nova fluidez, regeneração que a poesia vem precisando hoje. Tonus provoca o leitor, o homem, o pretenso humano, como se dissesse, "tem visto isto?" e logo depois conferisse a resposta do negligente ante ao indigente, o diferente, o vitimado, "Eu não ouvi o grito estrangulado da menina moldava ao ser estuprada na selva de Calais". (TONUS, 2018, p. 17). Como propõe Armando Gnisci (não exatamente sobre a Guerra civil na Síria e seus refugiados, ou outras situações históricas aludidas por Tonus, mas aqui cabivel para se pensar a responsabilidade de atenção ante todo aquele que se desloca para o estrangeiro):

Os dominados tendem sempre mais a mover-se, a deslocar-se. Chegam assim a constituir a voz do próprio tempo, visto que cada época tem uma voz que necessita se expressar e se fazer ouvir por aqueles que estejam dispostos a fazê-lo. Os donos da voz são os literatos, os artistas, os "filósofos" e os humanistas. São levados, pela experiência, a pensar, contudo, que são apenas eles que se dedicam à pesquisa da voz e da sua ascensão. Hoje, é necessário que eles mesmos abram os percursos para toda a humanidade que deseja liberar-se; de modo que o sentido possa ser ainda uma experiência imprevisivel e uma possibilidade de mudança e liberação. Não se trata apenas de resistência, mas de abertura para um futuro mais são para todos. (GNISCl, [2003], p. 1)

Nesse pressuposto de que dominados tendem a mover-se, e para, a priori, sequer pensar exatamente em refugiados, clandestinos ou expulsos, note-se que, na escala do planeta, no prodigiosamente emaranhado de liames subjetivos entre as nações, funciona esta força atrativa do locus-melhor para os imigrantes. Um dia isso funcionou para Tonus, evidentemente. ${ }^{4}$ Estes, fascinados ante territórios onde é mais desenvolvida a superestrutura da acumulação própria do nosso tempo (seja ela financeira, cultural, de memória, de possibilidades etc.), as disparidades tecnológicas e de oportunidades agravam as desigualdades e diferenças brutais com relação aos países subdesenvolvidos, o outro lado da balança, o que implica em um aumento deste atravessar fronteiras. Aumento derivado desde a diversificação de desejos e aspirações de mudanças, melhores condições de vida. Como diz Tonus: "caminho / porque tenho que caminhar / caminho" (TONUS, 2018, p. 31).

\section{Derrotas e desrotas}

Para o geógrafo Milton Santos, esta universalização perversa, como ele dirá em um tempo em que se começava a falar academicamente em globalização, é criada a princípio por interesses das multinacionais (das empresas do período técnico-científico). As empresas transnacionais criam o quadro da superutilização de recursos sociais e naturais. Nos paises desenvolvidos, a racionalidade da alienação, conforme Milton Santos, encontra contrapartida no emprego ou na ajuda financeira aos desassistidos, mas, nos países subdesenvolvidos ou "[...] no terceiro mundo, esta racionalidade permanece abstrata: o sistema não pode, aí, inventar uma falsa verdade para camuflar a realidade do não-emprego e da miséria" (SANTOS, 1994, p. 34). Note-se que, pela teoria de Milton Santos, o próprio espaço é um produto de mercado, ou um efeito, se tornou isso, no instante em que os homens carecem de buscar novos espaços e há uma convenção entre

\footnotetext{
4 Para Bauman, voluntários ou involuntários, os migrantes e os refugiados sempre foram assumidos como problemática do país hospedeiro. Como dirá ele: "Poucos, se é que algum, dos Estados-nação que preencheram o mapa-múndi moderno estavam fixados tão localmente quanto suas prerrogativas soberanas. Algumas vezes de boa vontade, outras com relutância, praticamente todos tiveram de aceitar a presença de estrangeiros no território apoderado e admitir sucessivas levas de imigrantes fugindo ou expulsos dos domínios de outros Estados-nação soberanos. Uma vez lá dentro, porém, tanto os estrangeiros estabelecidos quanto os recém-chegados caíam sob a jurisdição exclusiva e indivisa do país hospedeiro. Este último estava livre para apresentar versões atualizadas e modernizadas das duas estratégias descritas por Lévi-Strauss em Tristes trópicos como formas alternativas de lidar com a presença de estrangeiros. Recorrendo a essas estratégias, o país poderia contar com o apoio entusiástico de todas as outras potências soberanas do planeta, preocupadas em preservar o caráter inviolável da trindade território/Estado/nação [...]" (BAUMAN, 2004, p. 113).
} 
os interesses econômicos e os Estados. É mais ou menos dentro daquilo que Santos chamaria de "o espaço que une e separa" (SANTOS, 1994, p. 36), tempo em que "a unidade desumana da coisa" (SANTOS, 1994, p. 44) transforma o espaço em inimigo. Diante de tal conjuntura, onde o espaço é o inimigo, e diria que esta é a grande conjunturamotriz da poesia de Tonus, o poeta almeja ser aquele que convirá ao imprevisto, aquele que, ante tantas "desrotas", busca um caminho consciente do imprevisivel, do impreenchível. No ato da escrita, uma imaginável temperança:

Quero ser a mão de que servirá o imprevisto quando a escrita habitar meu pensamento inconsciente como uma queimadura.

Quero que minha voz migrante ecoe na espera do lugar algum.

Ocupar um lugar é sempre ocupar o lugar de alguém,

à sombra de nossa boa consciência,

sufocada no lodaçal da memoria

de derrotas

e desrotas

Abandonei a terra. A família; A casa da familia.

Perdi o giz da lousa nos cascalhos banhados pelas

ondas do mar.

Minha identidade é profunda.

Sou o ralo do mundo.

Um buraco

Um homem-buraco

que nada há de preencher.

Sem descendência, genealogias ou habitus

sou o bastardo que transforma o horizonte

em pontos de fuga

sem volta.

Minha identidade é profunda e suficientemente para

em meus braços amparar Querelle para

mergulharmos no poema do mar para

juntos ressurgirmos fragmentos

de nós mesmos.

Ouriços sem espinhos (TONUS, 2018, p. 40).
Com o giz perdido nos cascalhos banhados pelas ondas do mar, o professor-poeta reconhecese entre os clandestinos que atravessam o (m)ar com uma esperança/temperança. Tonus é um desterritorializado que não deixou de sonhar, mas não está, entretanto, literalmente na condição pura de clandestino ou refugiado, mesmo que domine o tema teoricamente realizando pesquisas acadêmicas sobre migração há muito tempo. Não deixa de ser, mesmo assim, um estranho, ou seja, de ser um homem que vive essa condição de estrangeiro ou exilado em outras terras. Contudo, ao fazer poesia, ao "mergulhar no poema do mar" (e o mar na sua poesia simboliza, acredito, em geral, a densa dimensão da fronteira), de alguma maneira, noto o perigo de que vejam suas tantas condecorações como sendo seus próprios espinhos (mesmo o diga "ouriço sem espinhos", sem "descendência, genealogia ou habitus"). Ao falar em primeira pessoa, o eu-lírico propõe sua sólida biografia qual um longo túnel escavado e onde, agora, o ouriço sai da toca, da troca, mostrando poeticamente o problema de ocupar-se uma identidade condecorada, decorada, temperada, quando subsiste rastros emocionais de algo mais profundo em deriva de toda uma vida de desidentitaridades intimas. Esse algo mais profundo que ainda o aproxima de Querelle 5 (palavra em francês, mas também poderia ser "dispute" ou "accrochage", quer dizer, talvez, nesse caso, esteja a dizer "combate", "conflito"). Ouro de ofício, ouriço, orifício.

Assim, por meio de louros, por um lado, ela (tal identidade condecorada) o tira, o re-tira, em certo sentido, de uma condição periférica (pelo viés do reconhecimento cultural, do acadêmico). Mas, por outro lado e por sua vez, justamente tal prosperidade alcançada solitariamente abre-lhe ou aprofunda-lhe o senso abismal de homem-buraco (o qual "nada há de preencher"). A vacuidade de ouriço indefeso, de homem estrangeiro marcado por uma escolha pessoal de abandono, de despedida (apesar de bemsucedida). Abandono intimo que jamais seria

5 Muito embora, "Querelle" seja, ali, referência explicita à personagem do Querelle de Brest de Jean Genet e que resultou no filme dirigido por Fassbinder, em 1982. 
preenchido por louros ou um reconhecimento individual, enquanto testemunhar o horror e a injustiça social rebentando ao seu entorno. Ou seja, acerca-se das dessubjetividades próprias do migrante, sendo ele ainda um professor brasileiro na França, embora as consequências dessa escolha, nesse caso, tenham sido altamente distintivas pela positividade do sucesso profissional. O eu-lírico abre-se em si mesmo e, sobretudo, para além de si mesmo.

Estamos a falar de desidentidade e não apenas de identidade nacional ou identificação identitária. Uma desidentidade melancólica? O problema desta melancolia em Tonus não é de dureza nostálgica, ou de desejar-se lugares inalcançáveis, longe tanto de um possivel banzo brasileiro, mas também longe de um spleen próprio de Paris. Pode parecer estranho entender-se e expressar-se como o ralo do mundo na cidade-luz, ainda mais na posição de estrangeiro altamente condecorado por seus órgãos oficiais. Entretanto, por suposto, vem a ser bem mais complexo bancar isso, por um certo prisma de compreensão, do que assumir o arquétipo marginal, digamos, de um cantor de o da periferia de São Paulo. Seria outra fenda psicológica, bem distinta e mais previsivel sobre o marginal enquanto margem. Tonus mistura erotismo e história, cilios que arrepiam de desejo e velhos sonhos de militância, subjetividade e comunidade, ou seja, ele não fala apenas pelo/do social, representando sua experiência individual em nome dos outros que não podem falar, ele fala de um terror que alude a todos, cuja resistência pode jazer no afeto, "vaga-lumes de uma história/ que gagueja/sonhávamos comunidades/de desejo./ sonhávamos desejos" (TONUS, 2018, p. 76). Posso dizer que é uma poética tanto dos desejos negados, quanto dos alcançáveis.

Falei em rap paulista, não há comparação realmente, mas, precisamente desde a condição na qual se encontra, é que Tonus pode bancar uma poesia de inclusão, ou de denúncia, que não seja exatamente de pura rebeldia sem interlocução, protesto ressentido, mas uma modalidade de revolta que lhe suscita oferecer generosamente a experiência da temperança, ao coletivar uma desidentidade capaz de fissurar ainda mais um buraco inominável. Um buraco dificil de ser posto em palavras. Inominável e paradoxal posto que é escavado, intelectualmente, ao mesmo tempo do se tentar fechá-lo, na ambivalente e blanchotiana gestualidade de voltar a pôr mãos à obra, onde a poesia como escolha, para não dizer método, torna ainda possivel a fluidez deste sentimento. Refiro-me ao de temperança, o de poder fazer algo com a escritura, com a "estrutura", desde um certo equilibrio humano. É o seu colocar em questão, colocar-se em questão. A poesia serve para o autor como um momento para pensar-se a si, cuidar-se de si mesmo, em um exercitar ethopoietico da palavra.

"Agora vai ser assim" (2018) retrata a opção pelo amor líquido, na vida mundializada e mundanizada, o imperativo da vida, mesmo com a impotência dos espinhos do migrante, seus fracos espinhos, fracas defesas. Trata-se também de, claro está, uma escolha pela poesia como a nova toca (toca do ouriço), pelo eco marginal, quando "a escrita habitar seu pensamento" (TONUS, 2018, p. 79), a opção de ainda querer que essa voz imigrante ecoe na espera do lugar algum, ou seja, trata-se da percepção de sua voz, as marcas desta afasia, a sua tatuagem exterior, anterior, sua repercussão, sua memória. Toda uma viagem marcada por derrotas e "desrotas" para se poder, enfim, escrever uma obra literária. E, nessa experiência, a escolha tinha de ser pelo gênero da poesia, espécie de oásis-miragem, rumor enganoso, pois ela torna plausivel estancar e ao mesmo tempo ferir mais a ferida; ela pode, com o jogo das assonâncias, gradações, ritmos, disposições etc., tangenciar toda uma dura questão inominável, em um atravessamento de risco, que sobrevive indefesa nesse "ouriço" (uma identidade mais profunda, mais "paradoxal"), e que deve ser lidada pela musicalidade, pela fluidez, pela temperança. Afinal, "Homens também choram/ as guerras/ e, à tarde, / suas lágrimas escorrem/ pelos nos das gravatas" (TONUS, 2018, p. 78). 


\section{Refugo como refúgio}

Em "Refúgio em Drummond", leio "sejamos o refúgio de um mundo refugo" (TONUS, 2018, p. 38), e penso nessas palavras "refúgio" e "refugo" que já iniciavam também o livro. A primeira poesia do livro intitulada "Amarelinha", vamos do "refugo" ao "refúgio", duas palavras bem pinçadas para a confecção do poema. Elas possuem, entre as silabas soltas, em uma brincadeira concretista, "fu", "re" e "jo". Sonoramente, desenvolvendo-as para "Fou" (louco); "ré" (dar a ré, voltar atrás), e "jo"; "yo" (eu). Pistas soltas desse jogo de amarelinhas onde se vai ao "céu", ao refúgio (liberdade de todo nomos), partindo-se do refugo (o mundo). Noto que o poema faz uma introdução em re-lance ao que será o livro como um todo, oscilação entre dois dados opostos, dois modos de criação, duas competências de escritura: um lado mais leve, outro mais pesado. O lado mais leve de Tonus é o seu lado feminino, resistente, intimo, generoso, o impressionismo do olhar e a delicadeza da temperança (cabalística). O lado mais pesado é o seu lado crítico, o lado que o permite falar desde um céu em (des)esperança, o poder, o lado trágico de uma sociedade humana que esmaga entre as pedras o diferente, em que o peso falocêntrico e naufrágio são constantes. Começar o livro assim é querer ser definido mais pelo lado leve, com isso a temperança surge, no céu da amarelinha. Conforme as regras de um jogo inocente de amarelinhas, um traço no chão é realizado com giz (em tempo, o mesmo perdido da lousa dos cascalhos, no caso de Tonus) e em que se marcam casas numeradas para se chegar, pulando com um pé só, ao "céu". Casas tais dispostas no formato quadrado, quais as silabas com duas letras do poema remetem, aludem, a uma forma quadrada. Como uma criança pequenina, o leitor é convidado a jogar o jogo, convidado por alguém que já tem asas lá no céu e conhece as regras ("agora vai ser assim"). O leitor está com a pedrinha de partida nas mãos, e ao ler a obra, cada página é uma surpresa, uma leitura inesperada, podendo o leitor cair em um lado ou outro, ao acaso.

\section{Amarelinha}

$\begin{array}{lcc} & \text { REFUGO } & \\ & \text { RE } & \\ \text { FU } & & \text { GO } \\ & \text { RE } & \\ & & \text { GO } \\ & \text { RE } & \end{array}$

REFUGIO (TONUS, 2018, p. 9).

A alusão à amarelinha concede esta pretensa leveza ao trágico. A inocência do brincar menino é, no entanto, mera ilusão, pois, logo em seguida, os temas mais pesados da obra vêm à tona, emergem. Temas profundos do contemporâneo, as fronteiras perversas, as travessias de rostos anônimos cheios de terror, o horror do Estado, o terror dos olhos clandestinos, como no poema "Terror":

\section{Terror}

Ontem eu vi o terror nos olhos de um imigrante clandestino. Simplesmente, o terror de um barco à deriva, vida de silêncios de uma existência usurpada.

Ontem eu vi o terror dos meus olhos nos olhos de um imigrante clandestino. Meus olhos menos clandestinos Desembarcados aqui há anos.

O terror não se descreve

O terror não se narra.

O terror não se esquece (TONUS, 2018, p. 13).

Como disse, a mão que retraça a amarelinha de Tonus, a cada virada de página, é a mesma que "abre mão" de quaisquer previsibilidades. Tal poema narra o olhar dentro do olhar do outro. Trata-se de um jogo de olhares, de miradas, onde o eu-lírico explica os olhos vistos de um imigrante clandestino cujo "terror" é reconhecido como o terror de seus olhos nos olhos do clandestino. Os olhares se perdem e se acham, ontem e hoje. Um velho terror o reconhece, ele é reconhecido pelo terror que jamais o giz da amarelinha pode apagar 
de suas cicatrizes incuráveis. Agora, olhos menos clandestinos, uma vez "desembarcado" há anos. No entanto, inesquecivel e inapagável, trata-se, possivelmente, do próprio poeta lendo-se. Mas, pode vir a ser também a lembrança do "ontem" a partir da mirada sobre um imigrante ilegal na França, ou um clandestino no sentido mínimo de exotópico à nova cultura, quer seja, o olhar consigo refletindo um sentimento inenarrável no sentido agambiano do testemunho impossivel de transmissibilidade.

Apenas a poesia é capaz de abeirar a isto, também aí, de maneira clandestina, quer seja, sem penetrar em uma essência do experimentado capaz de ser identificada, descrita, a poesia está neste locus à margem, à deriva, igualmente qual este barco de Tonus, de onde desembarca o "outro". Trata-se do outro que é outro, o outro que é Tonus. Novamente, a temperança, a hospitalidade, o reconhecimento, a comunicação. $\mathrm{Na}$ estrofe final, o poeta repete três vezes, "o terror não se...". Nessa anáfora ${ }^{6}$, a priori, expressa um reforço à autoridade, ao seu poder-dizer subjetivo desde a perspectiva de experiência do terror reconhecido pois um dia também vivido, mas que não será descrito e nem precisa ser. Por outro lado, ao usar da estratégia da anáfora, o poeta acaba demonstrando e reforçando este sentimento estrangeiro mais fácil de abordar pela negatividade, o terror é uma realidade dura cuja capacidade de transmissão apenas pode se dar pelo gesto muito bem temperado, nas intempéries do reconhecimento súbito de um outro que lhe (ao eu-lírico) rememora um terror. Ao citar frase de Mia Couto, no poema "No escuro", frase que diz "Quem vive no escuro inventa luzes", Tonus discorda dizendo "Inventa, mas não as pratica" (TONUS, 2018, p. 10). Pouco antes dizia de ascendentes vindos ao Brasil em porão de navio. Tonus reitera, novamente pela estratégia da tripla repetição de "veio ao Brasil no porão de um navio" (TONUS, 2018, p. 10), agora ao fim dos versos iniciais do poema, a intensidade deste reconhecimento. Então, ao negar a frase do cânone moçambicano é como se dissesse "vivi na prática certas invenções, não é fácil inventar luzes assim" (TONUS, 2018, p. 10). E, de fato, o poema conclui deste modo: "Eu vivo no escuro, / tateando muros/ entre rostos anônimos, / vidas nuas e/ mãos/ decepadas" (TONUS, 2018, p. 10).

Rostos anônimos olham o poeta. E esse, em temperança, não desvia o olhar. Por vezes a temperança de Tonus apenas faz fluir o desejo de se estar-em-comum. É o arcano da temperança enquanto hospitalidade de quem conhece a importância do acolhimento do outro anônimo, o desconhecido. Logo, apesar de tudo, este gesto é um gesto positivo e não negativo.

\section{Estar-em-comum}

A hospitalidade começa pela hospitalidade da língua.

nomear o outro que desconhecemos.

Acolher em nossa lingua

o outro

que não conhecemos.

Acolher a lingua do outro que nos é

desconhecida.

e, em troca, ofertar a nossa

um chá

café

ou simples copo-d'àgua.

\author{
Nada esperar \\ exceto o gesto da hospitalidade \\ um estar-em-comum \\ um respeitar-em-comum \\ um gesto \\ apenas (TONUS, 2018, p. 16).
}

Aqui, voltamos ao lado da leveza, o giz da amarelinha caiu do lado leve. O vaso de água cristalina, vidro espinhoso sobre a mesa, onde a temperança escorre o respeito, um gesto generoso e acolhedor de simples oferta sem nada pedir em troca. "Acolher em nossa lingua" pode ter um sentido equivoco, mas não necessário, posto que Tonus também abusa da intensidade erótica em muitos momentos.

6 Notei que Tonus abusa dessa figura de linguagem em seu método de composição. 


\section{4 Ética do trabalho}

Bauman alertava-nos sobre uma sociedade que ingressamos, pautada por uma "ética do trabalho" que assume outros sentidos, onde:

En otras épocas, la apología del trabajo como el más elevado de los deberes - condición ineludible para una vida honesta, garantía de la ley y el orden y solución al flagelo de la pobreza - coincidia con las necesidades de la industria, que buscaba el aumento de la mano de obra para incrementar su producción. Pero la industria de hoy, racionalizada, reducida, con mayores capitales y un conocimiento más profundo de su negocio, considera que el aumento de la mano de obra limita la productividad (BAUMAN, 2011, p. 75).

Sim, vale aqui relembrar Bauman quando postulava que, em um primeiro momento, a "ética do trabalho" surge a contrapelo das carências do processo de produção, ao início do século XIX, uma vez que aumentar a mão de obra era uma emergência industrial dos Estados. Como nos explicava, em Trabajo, consumismo e nuevos pobres, atravessamos há tempos esta realidade, e, assim, cada vez mais softwares eletrônicos suplantam trabalhadores, obrigando-os a buscar trabalho fora. A desocupação individual tem se tornado um problema iminente nas sociedades contemporâneas. E é assim que a chamada "redução de pessoal" foi se tornando paulatinamente uma necessidade das empresas. A indústria faminta por trabalho, no século XIX, exigia a laboração de uma "ética do trabalho", para se cumprir a mão de obra que era preciso. Mas, hoje, essa ética não tem mais sentido. Ao menos, não mais o mesmo uso de sentido. Não existe mais a velha hospitalidade, diria a poética de Leonardo Tonus. Acabou-se esse gesto que derroga solicitado como falta em "Agora vai ser assim", frequentemente, qual seja, a de uma ética da hospitalidade, de um estar-em-comum. Assim, nessa falta, nessa fenda, os imigrantes que buscam trabalho em outros países muitas vezes, e cada vez mais, são indesejados nos seus novos espaços (não mais espaços salváticos e sim, não raro, de uma segunda e mais profunda exclusão).

Las corporaciones ya no necesitan más trabajadores para aumentar sus ganancias, y, si llegan a necesitarlos, los encuentran fácilmente en otras partes y en mejores condiciones que en su pais, aunque esto contribuya a aumentar la pobreza en los países tradicionalmente considerados ricos [...] (BAUMAN, 2011, p. 73).

Mas, um papel ainda existe para aquela velha ética, a de fazer do pobre, do imigrante, do refugiado, do peregrino, um delito.

Ahora, cuando esa mano de obra pasó a ser
un obstáculo para aumentar la productivi-
dad, aquella ética todavia puede cumplir un
papel. Esta vez sirve para lavar las manos y la
conciencia de quienes permanecen dentro
de los límites aceptados de la sociedad: para
eximirlos de la culpa por haber arrojado a la
desocupación permanente a un gran número
de sus conciudadanos. Las manos y la con-
ciencia limpia se alcanzan, al mismo tiempo,
condenando moralmente a los pobres y ab-
solviendo a los demás (BAUMAN, 2011, p. 85).

O estrangeiro como delito, como refugo, é o terror de Tonus. A ausência de ética, nos gestos macros e micros, e as deturpações da velha ética do trabalho constituem seu tema. Acredito que o autor quer produzir uma poesia que reflita esta nova ordem social, uma nova ordem que perpassa muito pela questão da ética, ou do modo hipócrita como a velha ética é lida moralmente em função da latente necessidade de excluir. Nisso, o "respeitar-em-comum" que Leonardo Tonus solicita-nos é, em si mesma, uma nova ética, a da generosidade, a da hospitalidade, a do estar-em-comum, a do acolhimento da diferença em um gesto apenas que seja. Em um gesto que apenas seja, em um apenas seja gesto. Se todos tivessem o mesmo gesto, mesmo que em um sinal de desejo grupal, o respeito

\footnotetext{
7 Tonus cita Bauman, em uma entrevista a Marwio Câmara (Jornal Rascunho), quando questionado sobre a questão do "não pertencimento" presente em sua obra. Respondeu assim: "Eu me sinto como o cedro do filósofo Vilém Flusser: estrangeiro no meu parque, estrangeiro na França, estrangeiro no mundo. De fato, que relevância ainda há questionar-se acerca dos pertencimentos identitários no contexto da pós-modernidade? Como lembra Bauman, a noção de identidade é uma ficção forjada pelo Estado moderno. Somos seres atravessados por múltiplas identidades que vivem um constante não pertencimento. A experiência da expatriação só vem ressaltar este sentimento compartilhado, em minha opinião, por outros atores de nossa sociedade. Todo sentimento de pertencimento identitário é uma falácia que a literatura deve problematizar e desconstruir, interrogando o que o subjaz: a linguagem" (TONUS, "A poética de um expatriado", entrevista ao Jornal Rascunho, 2019).
} 
coletivo impor-se-ia como ato. Não teriamos nada a esperar (sua esperança). Não teriamos todo tipo de ressentimentos, paixões tristes, nada a lutar. Mas, o que se continua operando é o levante de muralhas, de orgulho, de diferença, de fronteira, de bandeiras cegas.

\section{Puta}

Em outros poemas, Tonus, coloca mais gravidade na balança, como no poema "Puta":

\section{Puta}

Você é estuprada por 36 homens

E ainda tem que provar a sua inocência.

Você é agredido fisicamente por ser negro

E ainda tem que provar a sua inocência.

Você é perseguido por ser gay

E ainda tem que provar a sua inocência.

Você é morto por não acreditar em um deus qualquer

E ainda tem que provar a sua inocência (TONUS, 2018, p. 19).

Nesse poema (eis acima a primeira estrofe), usando da anáfora para, como sempre, reiterar este peso, Leonardo Tonus sai mais da toca do ouriço ainda, apontando o dedo para funçõessujeito acorrentados na Lei, no nomos, subjetivo de uma sociedade onde você é vítima e ainda tem de provar a sua inocência. Ao repetir a frase tantas vezes, ao último verso, Tonus produz uma imagem surreal do morto tendo que ainda provar a inocência, o verso ali perde toda a razão, tornando-se ele mesmo uma frase totalmente de efeito. A violência contra um gay, um negro ou uma puta exigem um ato de prova. Mas, nos últimos versos deste trecho, a contradição de um nomos religioso, do fato de se ter fé ou não em um deus qualquer, e após assassinado por fiéis ter de provar a sua inocência, vale dizer que as bandeiras dogmáticas apenas geram contradições, nessa concepção do fanático assassino (terrorismos, fanáticos, lunáticos etc.). Gesto pequeno, como um "regard stupide" de que a morte é o de menos ante a ideologia do Terror sob o mandamento de um deus qualquer, um símbolo qualquer. Qualquer símbolo, qualquer dogmatismo, qualquer exagero provoca o combate entre os homens, onde pouco importa a prova do inocente. Novamente, o peso do Terror que, por vezes, retorna na poética de Tonus. O poema continua:
Obviamente,
Todas as mulheres são putas
Todos os negros bandidos
Todos os gays doentes
Todos os judeus ladrões
Todos os nordestinos incultos
Todo pobre vagabundo.

\begin{abstract}
A lista de novos mandamentos cresce
E minha indignação (TONUS, 2018, p. 19).
\end{abstract}

A ironia da palavra "obviamente", destacada como verso próprio, para iludir o olhar preconceituoso de que o poeta estaria desse lado, mas evidentemente é puramente irônico. A palavra faz a ponte, também, para uma atenção ao surgimento repentino do poeta, o eu-lírico, no verso cabal, onde a palavra é "indignação". O poema "Puta" é, talvez um dos mais fortes (pesados e diretos) do livro. Faz par com o poema "Um corpo sobre a areia", onde o poeta afirma "não há poesia no estupro/ Não há poesia no racismo / No feminicídio não há poesia." (TONUS, 2018, p. 14).

A palavra "pesado" (dividindo poemas de Tonus entre esses dois vasos do arcano da Temperança, ou seja, poemas leves e poemas pesados), aqui, é arbitrária, pois o próprio poeta confessa, no poema "21 gramas": "eu não sei o quanto pesa o arrepio das palavras" (TONUS, 2018, p. 46). Qual o peso de uma onda de mar? De um acorde de Gil Evans? Pergunta. Em verdade, Tonus estima "21 gramas/ o peso de sua alma/ ao morrer" (TONUS, 2018, p. 46), aludindo à crença do experimentalista americano do final do século XIX, Dr. McDougall, que acreditava neste peso da alma. O tema da morte reaparece em Tonus, seja em crianças que morrem como abelhas, como no poema "Abelhas de Ruanda", ou "Um corpo sobre a areia".

\section{Escrever com a vida: um gesto (fe)menino}

Transgressor multiforme, capaz de várias migrações de estilo, ele tira partido do político 
pela audácia de um escrever (fe)menino que a princípio teria tudo para nada perseguir no ponto de vista do político. É uma, como dissemos, ambivalente situação escritural. Percebo um poder de provocação subjetiva e de questionamento alfinetante sobre a brutalidade e a insuficiência de delicadeza e cortesia na atualidade. Continua o "retraçar" sociopolítico pela escrita como costura leve em uma dada militância, ou inquietude crítica, que sonega a patriarcalidade do identitarismo. "Retraçar", diria, no sentido abordado por Derrida em Essa estranha instituição chamada literatura, quando o filósofo propunha como "retrait", ou "retirada". Paradoxo do retrato, o que se retrata, se retira, como nos estudos do retrato feitos por Jean LucNancy. Quer seja, nenhuma busca desesperada de legitimação política pela voz combatente de homem, mesmo nenhuma busca política que, antes de qualquer coisa, não perpasse a ética. Esta ética é, em Tonus, a da temperança, da hospitalidade. Ética como gesto (fe)menino.

Mas, igualmente, não é possivel afirmar que houvesse alguma reserva, inibição, ou impotência do político em seu lado mais "leve" do livro como jogo de amarelinhas. Momentos mais pessoais, onde o poeta põe-se menos másculo (no sentido de uma força gritante contra o inimigo/ xenofobia). Ao contrário, uma obra em que o método composicional oscila, interessantemente, entre, por um lado, a ambivalência política de um autor bem afrancesado, já não mais periférico na Europa, resguardando o periferismo latino e mundial, com hospitalidade, mas, por outro lado, uma espécie de retiro do olhar para si mesmo. Mesmo neste outro lado de "Agora vai ser Assim", que pode ser considerado mais leve, o leitor constatará também as pinceladas do político e da insurgência contra a intolerância.

No curso mais do retiro interno, quando tece mais metalinguagens, por exemplo, no poema confessional "Despedida da Pedra", Tonus, busca proximidade aos clandestinos distantes e subversivos. Portando um espírito incendiário, de rebelde capaz de criar labaredas em nome de uma não bandeira. Como se dissesse "este sou eu", dizendo: "Hoje queimarei todos os meus livros / e meus dicionários./ Pelos becos da cidade / meus ensaios dilacerados espalharei. // Enterrarei meus poemas./ Meus pulsos cortarei./Hoje, meu sangue/ espargido/ tingirá/ nossas cartas/ sequer redigidas [...]" (TONUS, 2018, p. 47). Tonus escreve dramático nas ruinas do aqui e agora. Escreve com a vida dos que não podem falar e apenas caminham. Estampando, em temperança, aqueles que fracassando ou vencendo nas ruínas, ainda permanecem nelas, que, nos cacos da diferença, podem fazer alguma diferença maior. A diferença que fazem é a própria presença, a própria esperança.

Agora e aqui, Tonus consegue penetrar os entulhos da cidadela fortificada como "Cavalo de Troia". "Cavalo de Troia,/ verme/ e vírus,/ hoje, penetrarei teus circuitos labirínticos./ Arrancarei as teclas de tua velha Remington [...]" (TONUS, 2018, p. 47). As ruínas são a despedida da pedra, os dilaceramentos, a pirotecnia do imigrante pelos becos da sua escrita, uma poesia do fogo, do amor, daquele que está dramaticamente dividido, entre yin $x$ yang; leve $\times$ pesado; sombra $X$ luz; juventude $X$ velhice; silêncio $x$ palavra e dentro $x$ fora. Dividido entre margem $x$ centro. Os dois vasos condutores do arcano da Temperança. "Hoje, atarei fogo nas Bibliotecas" (TONUS, 2018, p.47). Essa poesia do fogo e da água, de um autor disposto a queimar tudo e reduzir a palavra a pó, eu-lírico como eu-poético capaz de enterrar seus poemas, clamar as línguas das labaredas, como articulará. A melange de escritura e fogo. Nela, note-se que o ato escritural se torna um pacto de sangue, de fogo, de amor, de entrega. Tonus não é um presente de grego, mas um presente universal. Revelação do ouriço sem espinhos, desentocado com esta obra, e capaz de uma desconstrução inteligente da paisagem presente, uma despedida bem-sucedida da pedra, escrever com a vida.

\section{Livro-denúncia, Livro-autodenúncia}

Agora vai ser assim é o livro de estreia de Leonardo Tonus, e, como propõe Cintia Moscovich, esta obra é quase um "livrodenúncia", como um dedo apontando "a aberração, o fato que se desvia do humanamente 
tolerável". Mas, esse dedo vem de fora, e de dentro, igualmente. Sou levado a acreditar, mais que um dedo apontando ao outro, no espaço, é também um dedo apontando a si mesmo também, para o seu lugar, as suas memórias, o que explica os buliçosos tons intimos abundados na produção em questão. E é difícil incluir-se em uma denúncia. Parafraseando Bauman, diria que "[...] imaginar la posibilidad de otra forma de convivencia no es el fuerte en nuestro mundo de utopias privatizadas" (BAUMAN, 2011, p. 111), mas Tonus o tenta pela arte. Como desdobraria Moscovich, o poeta em questão é identificado, assim, com "os despossuidos de todo tipo e em todo mundo" (MOSCOVICH, 2018, p.1). Acrescentaria, também, dentre eles, os que hoje superaram muitas diferenças e nem por isso deixaram de compreender este "ser-em-comum" da clandestinidade, da marginalidade, do caráter periférico que não pode estar apenas no passado. O migrante, o deslocalizado, comporta aberturas importantíssimas para o espaço novo, como nos proferiria o geógrafo Milton Santos, em suas reflexões socialistas sobre a natureza do espaço mundializado. Leonardo Tonus, percebo, extrai de sua essencial experiência uma contribuição de cicatrizes expostas, um presente large d'esprit, ele contribui também para uma desfetichização do imigrante como um puro "despossuido". O imigrante é o portador de uma memória, de uma experiência, de um valor, e, mesmo assimilado em outro espaço, ele contribui para a temperança deste novo espaço, para sua mestiçagem, o enriquecimento de relações subjetivas. A criação de novos imaginários, soluções, pontes. O imigrante é resultado também daquilo que, em Pensando o Espaço do homem, leríamos na denúncia de Milton Santos com relação ao fato crescente das ambições econômicas. Qual seja, a denúncia do quanto o Estado se torna um aliado ativo no curso da economia, ou dos interesses do econômico, esquecendo o papel do imigrante em outros enriquecimentos afetivos que não sejam cristalizados do plano financeiro, capital. "Os mecanismos de dominação são agora mais sistematicamente elaborados" (SANTOS, 1994. p. 21). Santos se referiria ao periodo técnicocientífico que precederia o técnico-científicoinformacional, tal como ele avocará na terceira parte de sua obra mais profunda A Natureza do Espaço. Técnica e Tempo, Razão e Emoção. Um período onde a brutalidade das transformações mundiais em uma sociedade de superexploração e superacumulação (SANTOS, 1994, p. 19) nos proporia uma universalização perversa que impõe a experiência do estrangeiramento forçado nos homens.

Talvez não seja exatamente o caso biográfico de Leonardo Tonus, mas não significa que ele, na função-sujeito de estrangeiro, nessa suspensão duradoura, não comporte muitas das tantas questões subjetivas próprias do migrante refugiado. Tonus nos enriquece, intelectual e sentimentalmente, desde sua condição subjetiva marginal, desde sua peregrina temperança. Milton Santos lembra, justamente, do enriquecimento das relações interpessoais a partir da presença do migrante em um novo espaço, posto que, enquanto a mnemes seria coletiva, o (re)conhecimento seria individual. Milton Santos dirá que:

[...] o homem de fora é portador de uma me-
mória, espécie de consciência congelada,
provinda com ele de um outro lugar. O lugar
novo o obriga a um novo aprendizado, na nova
formulação. A memória olha para o passado, a
nova consciência olha para o futuro. O espaço
é um dado fundamental nesta descoberta
(SANTOS, 1994, p. 224).

Assim, Tonus também sabe que o imigrante enriquece o espaço, desde tanto uma experiência da escassez a qual é/foi vitimado, quanto das várias autorrenúncias operadas para conviver na diferença. No entanto, seguramente, o imigrante precisa se modificar muito mais do que aquilo que ele pode mudar em um espaço novo. Assim, o migrante pode até se sentir "refugo", na linha que apontaria Milton Santos, em uma perspectiva de ter que se adaptar ao espaço que o oprime subjetivamente, em geral, exigindo um razoável apagamento de suas memórias individuais em prol da adaptabilidade ao coletivo, ao espaço novo. Ou seja, tento notar aqui uma aproximação entre as reflexões de Milton Santos e os versos 
de Leonardo Tonus, pois ambos arriscariam notar aquele que migra como uma oportunidade no espaço que é afetiva, subjetiva (não meramente econômica). Para Tonus, deve haver uma inversão no que tange a uma potencialização do migrante como "refúgio" e não "refugo". Nesse sentido, lemos um poema como o "Refúgio em Drummond" (embora o poeta itabirano, mesmo com a tamanha universalidade de sua obra, tivesse uma biografia marcada pela experiência identitária local, em Minas):

\section{Refúgio em Drummond}

Não nos afastemos

Não nos afastemos muito

Não nos afastemos nunca.

De mãos, braços, pernas e corpo dados

Uns com os outros

Uns aos outros

Sejamos o refúgio de um mundo

Refugo (TONUS, 2018, p. 38).

É o mundo que, por uma operação ética e poética de virar ao avesso as interpretações, diante da perspectiva do afeto possivel desde a compreensão do diferente, se torna refutado. O mundo, diante desta perspectiva amorosa, se torna "refugo". O refúgio é, por sua vez, o imigrante: aquele que, (in)justamente, em uma nova moral da ordem do social é, constantemente, colocado como o jogador impotente e indolente (como diria Bauman). Ele acaba, em Tonus, ao contrário, lido como o refúgio (e o poeta se localiza ali) de uma sociedade paranoica, intolerante e de valores-refugos.

\section{Considerações finais}

A capacidade de refúgio do estrangeiro é a de desestabilizar a maquinaria dos confortos privativos que isolam os homens, esquecidos desse contato físico, corporal, uns aos outros, com os outros, homens que se afastam sempre. Logo, não nos afastemos nunca. Sejamos o refúgio de um mundo refugo. A temperança da poesia de Leonardo Tonus.

\section{Referências}

AGAMBEN, Giorgio. Homo sacer: O poder soberano e vida nua. Belo Horizonte: Ed. UFMG, 1995.

AGAMBEN, Giorgio. O que resta de Auschwitz: o arquivo e o testemunho (Homo Sacer III). São Paulo: Boitempo Editorial, 2008.

AMOREIRA, Flavio Viegas. Leonardo Tonus, poesia social. 2018. Disponivel em: https://levaumcasaquinho.blogspot.com/2018/06/leonardo-tonus-poesia-social-por-flavio.html.

BAUMAN, Zygmunt. Trabajo, consumismo y nuevos pobres. Barcelona: Gedisa, 2011.

BAUMAN, Zygmunt. Amor Liquido. Sobre a fragilidade dos laços humanos. Trad. Carlos Alberto Medeiros. Rio de Janeiro: Jorge Zahar, 2004.

DERRIDA, Jacques. Esta estranha instituição chamada Literatura. Trad. de Marileide Dias Esqueda. Belo Horizonte: Editora UFMG, 2014.

GINISCl, Armando. Migração e literatura. Tradução da Profa. Dra. Shirley de Souza Gomes Carreira. Revista Eletrônica do Instituto de Humanidades, v. II, n. VII, out.-dez., 2003.

NETO, Raimundo. Agora vai ser assim de Leonardo Tonus e o exercício da alteridade. São Paulo Review, 2019 Disponivel em: saopauloreview.com.br/agora-vai-ser-assim-de-leonardo-tonus-e-o-exercicio-da-alteridade.

SANTOS, Milton. Técnica, espaço, tempo: globalização e meio técnico-científico informacional. São Paulo: Hucitec, 1994

SANTOS, Milton. Pensando O espaço do Homem. São Paulo: Hucitec, 1982

SANTOS, Milton. A natureza do espaço: técnica e tempo, razão e emoção. São Paulo: Hucitec, 1996.

TONUS, Leonardo. A Poética de um expatriado. Entrevista a Mário Câmara. Jornal Rascunho, Curitiba. Disponivel em: http://rascunho.com.br/a-poetica-de-um-expatriado/.

TONUS, Leonardo. Agora vai ser assim. São Paulo: Editora Nos, 2018.

\section{Daniel de Oliveira Gomes}

Doutor e mestre em Literatura pela Universidade Federal de Santa Catarina (UFSC, Florianópolis, SC, Brasil), atualmente em estágio pós-doutoral junto à Université Paris Nanterre (UPN, Paris, França) no Centre de Recherches Interdisciplinaires sur le monde Lusophone (CRILUS). Leciona na Pós-graduação em Estudos da Linguagem junto à Universidade Estadual de Ponta Grossa (UEPG, Ponta Grossa, PR, Brasil), onde é também vinculado como professor associado nos Cursos de Letras, área de Literatura. 


\section{Endereço para correspondência}

Daniel de Oliveira Gomes

Universidade Estadual de Ponta Grossa

Programa de Pós-Graduação em Estudos da Linguagem

Praça Santos Andrade, 01, Bloco B, sala 102

Centro, 84010-330

Ponta Grossa, PR, Brasil 